\title{
TINJAUAN YURIDIS PENENGGELAMAN KAPAL ASING MENURUT UNDANG-UNDANG NOMOR 45 TAHUN 2009 TENTANG PERIKANAN
}

\author{
Elisabeth Septin Puspoayu ${ }^{*}$, Bunga Nurani ${ }^{2}$, Esti Wulan Trityas ${ }^{3}$, Maulida Indah Sari ${ }^{4}$, Mayang \\ Chandra Gita Siti ${ }^{5}$, Allafa Qori'atul Muzayyanah ${ }^{6}$ \\ 1,2, 3,4,5,6 Fakultas Ilmu Sosial dan Hukum, Universitas Negeri Surabaya, Surabaya \\ *Koresponden: elisabethpuspoayu @unesa.ac.id
}

\begin{abstract}
Amendment to the United Nations Convention on the Law of the Sea of 1982 with Law No. 17 the Year 1985 makes Indonesia have the right to utilize, conservation, and manage fish resources in Indonesia's exclusive economic zone and the high seas. Such rights are exercised under applicable international terms or standards. Therefore, legislation was made related to the sinking of illegal fishing vessels in Indonesian territorial waters through Law No. 45 of 2009 on Fisheries. Indonesia's high wealth of marine resources does not run following all layers' expectations after illegal fishing. However, the juridical consequences of applying the law have several impacts, namely the impact of sinking foreign vessels on relations with foreign countries and negative-positive effects in the marine environment due to the sinking of foreign vessels illegal fishing actors.
\end{abstract}

Keywords: Illegal Fishing; IUU Fishing.

\begin{abstract}
Abstrak
Ratifiksi terhadap Konvensi Perserikatan Bangsa-Bangsa tentang Hukum Laut Tahun 1982 dengan UU No.17 Tahun 1985 tentang Pengesahan United Nations Convention on The Law of the Sea 1982 membuat Indonesia memiliki hak untuk melakukan pemanfaatan, konservasi, dan pengelolaan sumber daya ikan di zona ekonoini eksklusif Indonesia dan laut lepas. Tentunya hak tersebut dilaksanakan berdasarkan persyaratan atau standar internasional yang berlaku. Karena itu dibuatlah peraturan perundangan terkait dengan penenggelaman kapal pelaku Illegal Fishing di wilayah perairan Indonesia melalui Undang-undang Nomor 45 Tahun 2009 tentang Perikanan. Tingginya kekayaan sumber daya kelautan yang dimiliki oleh Indonesia, pada dasarnya tidak berjalan sesuai dengan harapan seluruh lapisan setelah adanya Illegal Fishing. Namun konsekuensi yuridis dari penerapan undang-undang tersebut menimbulkan beberapa dampak yakni dampak penenggelaman kapal asing terhadap hubungan dengan negara asing dan juga dampak positif negative di lingkungan laut akibat dari penenggelaman kapal asing pelaku Illegal Fishing tersebut.
\end{abstract}

Kata Kunci: Illegal Fishing; IUU Fishing.

\section{A. PENDAHULUAN}

Indonesia adalah negara dengan luas wilayah terbesar kedua di wilayah asia tenggara, luas wilayah laut Indonesia lebih luas dibandingkan dengan luas wilayah darat yakni sepertiga berupa wilayah darat dan dua pertiga merupakan wilayah laut. ${ }^{1}$

\footnotetext{
${ }^{1}$ Frans E. Lidkadja and Daniel F. Bassie, Hukum Laut Dan Undang-Undang Perikanan (Jakarta: Ghalia Indonesia, 1985).
} 
luas wilayah laut Indonesia, sumber daya di wilayah laut ini sangat banyak pula dan dapat dimanfaatkan untuk memenuhi kebutuhan nasional. Sebagian besar rakyat Indonesia hidup dari hasil yang diperoleh di wilayah laut, berupa hasil perikanan dan sumber daya alam hayati lainnya. Hal ini berarti bahwa pemanfaatan sumber daya perikanan harus seimbang dengan daya dukungnya, sehingga diharapkan dapat memberikan manfaat secara terus menerus. Salah satunya dilakukan dengan pengendalian usaha perikanan melalui pengaturan pengelolaan perikanan (Penjelasan Umum Undang-Undang Nomor 45 Tahun 2009 Tentang Perikanan).

Potensi besar yang dimiliki Indonesia dalam dunia Perikanan memunculkan permasalahan-permasalah dalam dunia perikanan sendiri. Permasalahan yang banyak muncul dan berpotensi menganggu perekonomian nasional Indonesia dalam memanfaatkan sumber daya perikanan dan kelautan yakni praktik pencurian ikan atau yang bisa disebut dengan Illegal Fishing yang merupakan bagian dari IUUF (Illegal, Unregulated and Unreported Fishing Practices) oleh nelayan-nelayan asing maupun nelayan lokal yang menggunakan armada kapal ikan asing dan alat tangkap ikan yang dapat merusak ekosistem laut. ${ }^{2}$ Praktik Illegal Fishing tersebut merupakan permasalahan yang paling banyak merugikan negara termasuk Indonesia sebgai negara kepulauan. Beberapa macam tindak pidana di bidang perikanan (IUU Fishing : Illegal, Unregulated, Unreported Fishing) dapat dibedakan atas ${ }^{3}$ illegal fishing, Unregulated Fishing dan Unreported Fishing.

Penangkapan ikan secara illegal, atau yang disebut pencurian ikan (Illegal Fishing) sangat merugikan negara pantai dan kepulauan yang memiliki nelayan tradisional. Nelayan tradisional yang menggantukan kehidupannya dengan mencari ikan di wilayah laut negara pantai maupun negara kepulauan merupakan pihak yang paling dirugikan dengan adanya kegiatan IUUF di wilayah kedaulatan maupun hak berdaulat suatu negara pantai maupun negara kepulauan. ${ }^{4}$ Selain itu, masyarakat lain yang merupakan konsumen juga ikut dirugikan karena tidak bisa menikmati hasil laut di negeri sendiri. Secara makro, Ikan-ikan Indonesia yang dicuri lantas diolah dengan peralatan mumpuni sehingga meningkatkan harga jualnya di luar negeri. ${ }^{5}$

Masyarakat pesisir Indoneia yang berprofesi sebagai nelayan yang menggantungkan hidupnya di wilayah laut Indonesia Bersama dengan nelayan asing yang juga mengambil ikan di wilayah Zona Ekonomi Eksklusif Indonesia tidak jarang melakukan Tindakan yang melanggar hukum yakni illegal fishing. Nelayan asing yang melakukan Illegal Fishing ini menangkap ikan di laut Indonesia secara besar-besaran dan dengan cara yang dapat merusak habitat ikan di dalam laut seperti menangkap ikan menggunakan bom yang dapat mengakibatkan kerusakan wilayah laut Indonesia.

Pemerintah Indonesia melalui kementerian kelautan dan perikanan melakukan penerapan sanksi salah satunya dengan penenggelaman kapal nelayan pencuri ikan. Kebjakan

\footnotetext{
${ }^{2}$ Elisabeth Septin Puspoayu and Peni Jati Setyowati, "Illegal, Unreported, and Unregulated Fishing as Transnational Organized Crimes," SHS Web of Conferences 54 (2018): 05003, https://doi.org/10.1051/shsconf/20185405003.

${ }^{3}$ Edi Anjarotni Dkk, Analisis Dan Evaluasi Hukum Tentang Pengadilan Perikanan (Jakarta: Badan Pembinaan Hukum Nasional, 2009).

${ }^{4}$ Septin Puspoayu and Jati Setyowati, "Illegal, Unreported, and Unregulated Fishing as Transnational Organized Crimes."

${ }^{5}$ Djoko Tribawono, Hukum Perikanan Indonesia (Jakarta: Citra Aditya Bakti, 2011).
} 
E-ISSN :

ISSN :

ILREJ, Vol. 1, No. 1, Maret 2021

ini terdapat dalam Pasal 69 ayat (4) Undang-Undang Nomor 45 Tahun 2009 tentang

Perikanan. Hal ini merupakan Konsekuensi hukum atas diratifikasinya Konvensi Perserikatan Bangsa-Bangsa tentang Hukum Laut Tahun 1982 dengan Undang-Undang Nomor 17 Tahun 1985 tentang Pengesahan United Nations Convention on The Law of the Sea 1982 menempatkan Negara Kesatuan Republik Indonesia memiliki hak untuk melakukan pemanfaatan, konservasi, dan pengelolaan sumber daya ikan di zona ekonoini ekskiusif Indonesia dan laut lepas yang dilaksanakan berdasarkan persyaratan atau standar internasional yang berlaku.

Ketentuan Pasal 73 UNCLOS 1982 menyatakan bahwa hak berdaulat dalam zona ekonomi eksklusif merupakan mutlak milik negara pantai. Dalam penegakan hukum akibat ulah para nelayan asing yang mencuri dan mengambil ikan tanpa ijin di wilayah perairan Indonesia, pemerintah memberlakukan sanksi berupa sita dan penenggelaman kapal ikan pencuri ikan yang ditangkap dan telah sesuai putusan pengadilan yang sesuai dengan UU no 45 tahun 2009 tentang perikanan. Pemberian sanksi dengan cara penenggelaman kapal merupakan upaya negara dalam memberantas kegiatan perikanan yang dilakukan secara illegal. ${ }^{6}$ Pemberian sanksi dengan cara penenggelaman merupakan upaya negara dalam memberantas kegiatan perikanan yang dilakukan secara illegal dan disamping itu juga untuk memberikan suatu efek jera atau menangkal terhadap pelanggaran di Wilayah Perbatasan atau di Luar Perbatasan Laut Indonesia yang dapat merugikan dan mengancam kedaulatan negara. ${ }^{7}$

Berdasarkan pendahuluan diatas maka permasalahan yang akan dibahas dalam tulisan ini adalah bagaimana dampak yang timbul akibat tindakan penenggelaman kapal asing diwilayah perairan Indonesia.

\section{B. METODE PENELITIAN}

Penelitian ini menggunakan jenis penelitian hukum normatif yang dilakukan dengan meneliti bahan Pustaka atau data sekunder yang terdiri dari bahan hukum primer dan bahan hukum sekunder berupa buku hukum laut internasional, jurnal dan hasil penelitian yang berhubungan dengan adanya illegal fishing di wilayah zona ekonomi ekslusif dan pendapat para pakar hukum laut internasional. Penelitian ini akan disusun menggunakan tipe penelitian yuridis-normatif, yaitu penelitian yang mengkaji penerapan kaidah-kaidah atau norma-norma dalam hukum positif.

Penelitian hukum ini mencari kebenaran koherensi yakni adakah aturan hukum sesuai dengan norma hukum, adakah norma sesuai dengan prinsip hukum, dan apakah tindakan sesuai dengan norma hukum atau prinsip hukum, serta melakukan pemecahan masalah untuk memberikan preskripsi atas isu hukum yang diajukan ${ }^{8}$.

\footnotetext{
${ }^{6}$ Haryanto and Joko Setiyono, "Kebijakan Penenggelaman Kapal Asing Pelaku Illegal Fishing Oleh Pemerintah Indonesia Dalam Persfektif Hukum Pidana Internasional," Law Reform 13, no. 1 (2017): 70, https://doi.org/10.14710/lr.v13i1.15952.

${ }^{7}$ Desi Yunitasari, "Penegakan Hukum Di Wilayah Laut Indonesia Terhadap Kapal Asing Yang Melakukan Illegal Fishing Mengacu Pada Konvensi United Nations Convention on Law of the Sea 1982," Jurnal Pendidikan Kewarganegaraan Undiksha 8, no. 1 (2020): 61-78.

${ }^{8}$ Depri Liber Sonata, "Metode Penelitian Hukum Normatif Dan Empiris: Karakteristik Khas Dari Metode Meneliti Hukum,” Jurnal Justicia 8, no. 1 (2008): 24.
} 
E-ISSN:

ISSN :

ILREJ, Vol. 1, No. 1, Maret 2021

\section{PEMBAHASAN}

\section{Dampak Penenggelaman Kapal Terhadap Hubungan Dengan Negara Asing}

Di era globalisasi ini dimana hubungan antar negara menjadi sesuatu yang penting, terlebih hubungan Indonesia dengan negara-negara tetangganya, Tindakan tegas suatu negara kepada warga negara asing tentu saja akan mempengaruhi hubungan baik kedua negara. ${ }^{9}$ Tindakan pemerintah Indonesia yang menenggelamkan kapal asing tanpa bernegosiasi dengan negara asalnya dapat mempengaruhi hubungan baik kedua negara.

Pada tanggal 5 Desember 2014 tiga Kapal asal Vietnam melakukan tindakan Illegal Fishing di perairan Indonesia ditenggelamkan TNI AL, akibat dari peristiwa tersebut pemerintah Vietnam melalui Kedubesnya di Jakarta melayangkan protes. ${ }^{10}$ Kedua negara sepakat untuk memperlambat peningkatan kerja sama diantara kedua pihak. Indonesia sedang dalam masa negosiasi dengan Vietnam untuk menentukan batas wilayah perairan masingmasing negara agar tidak terjadi lagi konflik perebutan wilayah oleh kedua negara tersebut.

Selain Vietnam, negara yang protes terhadap peneggelaman kapal pelaku Illegal Fishing yang dilakukan oleh Indonesia adalah China. Hubungan antara Indonesia dengan China, hingga hari ini masih berjalan baik meski ada peberlakukan mengenai hukuman penenggelaman kapal pencuri ikan yang berasal dari China sendiri, namun protes dengan nota diplomasi dilakukan oleh China pada awal pemberlakuan penenggelaman kapal bagi para nelayan yang kedapatan melakukan pencurian ikan. Indonesia sudah menjelaskan kepada China mengenai alasan-alasan pemerintah yang menenggelamkan dan membakar kapal ikan asing pelaku Illegal Fishing. ${ }^{11}$ China juga menyampaikan protesnya pada setiap pertemuan bilateral kedua negara seperti pertemuan di Beijing. ${ }^{12}$

Dilihat dari segi hukum, terdapat pasal yang mengatur penenggelaman kapal pencuri ikan,walaupun melalui kebijakan penenggelaman kapal memungkinkan adanya konflik atau hubungan antar negara menjadi tidak baik, namun sudah seharusnya negara yang baik adalah negara yang menentang segala bentuk kejahatan yang dilakukan warga negaranya di negara lain dan menghargai setiap kebijakan dan hukum yang berlaku di negara lain. Bahwa mengenai penenggelaman kapal asing merupakan hak berdaulat dari negara pantai yakni Indonesia, jadi semua negara harus menghimbau masyarakat khususnya nelayan utnuk tidak masuk ke wilayah perairan laut Indonesia secara ilegal.

\section{Dampak Penenggelaman Kapal Terhadap Lingkungan Laut}

a. Dampak Negatif Penenggelaman Kapal Terhadap Kondisi Perikanan Dan Kelautan Indonesia

Mengenai penenggelaman kapal asing yang melakukan praktik illegal fishing yang dilakukan oleh Indonesia ternyata memiliki dampak terhadap perikanan dan kelautan Indonesia. Kebijakan penenggelaman kapal ini telah di atur dalam Undang-undang Nomor 45

\footnotetext{
${ }^{9}$ Kup Yanto Setiono, "Bela Negara Dalam Perspektif Strategi Dan Kebijakan Pertahanan Negara Edisi Khusus 2017," Wira Media Informasi Kementerian Pertahanan, 2017, 6.

${ }^{10}$ Edwin Firdaus, "Vietnam Protes Penenggelaman Kapal, Tiongkok Minta Penjelasan,” Tribun News, 2014.

${ }^{11}$ Kementrian kelautan dan perikanan, Laporan Kinerja Kemenrian Kelautan Dan Perikanan 2017, 1 st ed., vol. 1 (jakarta: KKP, 2017), http://kkp.go.id/an-component/media/upload-gambar-pendukung/kkp/LKJ-KKP-2016Revisi-18-Mei-2017-1.pdf.

12 Serina bibina Br. Ginting, "Pengaruh Pemberantasan Illegal Fishing Di Perairan Indonesia Terhadap

Hubungan Bilateral Indonesia Dengan Negara Lain,” JOM II, no. II (2015).
} 
Tahun 2009 Tentang Perikanan. ${ }^{13}$ Tindakan penenggelaman kapal ini sebenarnya dilakukan agar menimbulkan efek jera bagi pelakunya. Tindakan ini akan menimbulkan efek jera karena kapal tersebut merupakan alat produksi utama pelaku pencurian. ${ }^{14}$ Jika kapal dan perlengkapannya ditenggelamkan, pencuri akan ragu untuk mengulangi aksi illegal fishing di wilayah Indonesia. Tindakan ini juga sebagai bentuk atas ketegasan pemerintah Indonesia untuk menghentikan praktik illegal fishing. Namun sebenarnya tindakan penenggelaman kapal ini juga memiliki dampak negatif terhadap kondisi perikanan dan kelautan Indonesia. Kebijakan penenggelaman kapal ini di anggap kurang bersahabat, di anggap tidak ramah lingkungan dan tidak diplomatik dengan negara lain. Dapat di lihat dari banyaknya kapal yang telah ditenggelamkan pemerintah Indonesia, di kutip dari fakta news total dalam kurun waktu 2014 hingga 2017, sekitar 683 unit kapal yang telah ditenggelamkan. ${ }^{15}$

Dampak negatif tersebut akan timbul apabila tidak dilakukan pembersihan serpihan bahkan badan kapal utuh yang ditenggelamkan. Hal tersebut tentu mengganggu pelayaran atau transportasi kapal-kapal kecil. Bahkan penenggelaman tersebut dapat membahayakan keselamatan pihak yang ada di dalam awak kapal. Selain itu di anggap tidak ramah lingkungan, hal ini karena badan kapal yang tenggelam akan mengenai terumbu karang dan menyebabkan rusaknya terumbu karang. Seperti yang kita ketahui terumbu karang adalah sistem bawah laut yang terdiri dari sekelompok binatang karang, terlebih lagi juga menjadi rumah bagi ikan ataupun tempat berlindung bagi ikan-ikan kecil. Dapat di lihat dari banyaknya spesies laut yang ditemukan di terumbu karang. Jika kapal yang tenggelam tersebut mengenai terumbu karang dan menyebabkan kerusakan bahkan kehancuran, maka akan mempengaruhi kondisi perikanan dan kelautan itu sendiri.

Selain itu, kandungan logam berat dari kapal juga dapat menyebabkan tercemarnya air laut dan mengancam terjadinya keracunan terhadap biota air dan lingkungan sekitar laut. Logam berat yang di maksud di sini yaitu seperti timbal, nikel, dan aluminium. Logam memiliki efek berbahaya bagi pencemaran karena sifat logam yang tidak dapat diuraikan. Tercermarnya perairan laut juga dimungkinkan terjadi karena bocornya bahan bakar kapal yaitu solar bahkan fosil. Hal ini jelas akan menyebabkan dampak buruk bagi perikanan dan kelautan Indonesia sendiri karena bahan bakar tersebut terbuat dari batu bara, minyak bumi, dan gas alam yang mengandung karbon dengan presentase tinggi. Terkontaminasinya air laut dapat menyebabkan ikan menjadi keracunan.

Hal ini dapat dikatakan sebagai pencemaran laut yang dapat menimbulkan kerusakan ekosistem laut, seperti kerusakan terumbu karang, dan matinya biota laut. Karena dalam kapal pastinya juga ada bahan yang terbuat dari plastik maupun kayu, penenggelaman kapal juga dapat menyebabkan keindahan laut berkurang karena keberadaan tumpukan kerangka kapal dan barang-barang yang terapung. Imbasnya ekosistem laut menjadi terganggu akibat banyak benda asing di perairan yang mengganggu kehidupan ikan dan pemandangan. Selain itu

\footnotetext{
${ }^{13}$ Firdaus, "Vietnam Protes Penenggelaman Kapal, Tiongkok Minta Penjelasan."

14 firmansyah abdul, "Pencurian Ikan Oleh Kapal Asing Di Wilayah Teritorial Indonesia Dalam Presfektif Hukum Positif Indonesia," Lex et Societatis 4, no. 1 (2016): 155-64, https://ejournal.unsrat.ac.id/index.php/lexetsocietatis/article/view/11153/10743.

${ }^{15}$ Admin, "Dampak Pemberantasan Illegal Fishing Dan Penenggelaman Kapal Produksi Ikan Indonesia Meningkat Signifikan," Fakta News, 2017.
} 
sampah plastik jika dibiarkan terus berada di lautan, maka akan memungkinkan akan terbawa ombak dan sampai ke pantai. Hal ini karena sampah plastik merupakan sampah yang membutuhkan waktu yang cukup lama untuk dapat terurai, dan menyebabkan lingkungan pantai Indonesia yang kotor.

Dalam praktiknya, penenggelaman kapal FV Viking pada tahun 2016 menyebabkan pencemaran di laut pangandaran, Jawa Barat. ${ }^{16}$ Pengenggelaman tersebut menyebabkan kapal itu bocor sehingga mencemari air laut dan pantai di sekitarnya. Akibatnya ekosistem laut rusak padahal air di tempat tersebut jernih serta memiliki habitat bawah laut yang masih terjaga, sehingga nelayan sulit mendapat ikan dan masyarakat kehilangan mata pencarian.

\section{b. Dampak Positif Penenggelaman Kapal Terhadap Kondisi Perikanan Dan Kelautan Indonesia}

Tingginya kekayaan sumber daya kelautan yang dimiliki oleh Indonesia, pada dasarnya tidak berjalan sesuai dengan harapan seluruh lapisan setelah adanya illegal fishing. ${ }^{17}$ Potensi perikanan seharusnya mampu dimanfaatkan secara maksimal oleh pemerintah melalui KKP dan nelayan Indonesia. Dengan memperketat penjagaan di wilayah yang berpotensi terjadi pencurian ikan maka pemanfaatan akan lebih maksimal. Oleh karena itu, keamanan kelautan di Indonesia harus terus dikembangkan. Hal ini karena potensi tersebut berperan penting dalam pembangunan Indonesia terutama dalam bidang ekonomi bagi para nelayan dan masyarakat Indonesia pada umumnya. ${ }^{18}$

Hal ini merupakan langkah awal, kedepan tindakan tegas berupa penengggelaman kapal asing pelaku Illegal Fishing akan terus dilakukan untuk menimbulkan rasa jera kepada pelakunya. Tindakan tegas berupa penenggelamkan kapal asing yang melakukan tindak pidana Illegal Fishing wilayah laut Indonesia, bertujuan untuk menunjukkan ketegasan dan keseriusan Pemerintah Indonesia dalam melindungi kedaulatan wilayah dan hasil alam yang dimilikinya, serta, diharapkan dapat menimbulkan efek jera, sekaligus wujud nyata upaya Pemerintah untuk menerjemahkan visi poros maritim yang tengah digencarkan pemerintah dalam satu tahun terakhir, terutama yang berkaitan dengan kedaulatan penuh di laut. ${ }^{19}$ Dengan kebijakan ini, kapal nelayan asing yang akan melakukan pencurian di laut Indonesia akan berpikir dua kali untuk melakukan pencurian.

Meskipun banyak menimbulkan kerugian dari tindakan Illegal Fishing, disamping itu ada dampak positifnya yaitu pemerintah Indonesia dapat menghentikan aktivitas pencurian ikan serta menyelamatkan habitat perairan di dalam laut dari bahaya bom nelayan asing. Selain itu, kebijakan ini juga memberikan keuntungan bagi nelayan lokal Indonesia yaitu meningkatkan perikanan dan kelautan di Indonesia. Perekonomian Indonesia sudah mulai meningkat di bidang ekonomi laut, sedangkan Vietnam yang selama ini menjadi pemasok untuk pasar internasional sudah tidak mampu lagi mencukupi kebutuhan pasar internasional karena banyak kapal ikan negara tersebut yang selama ini menangkap ikan di Indonesia sudah ditangkap oleh pemerintah Indonesia.

\footnotetext{
${ }^{16}$ Septian Denny, “Kapal Yang Ditenggelamkan Menteri Susi Cemari Laut?,” Liputan 6, 2016.

17 Simela Victor Muhamad, "Illegal Fishing Di Perairan Indonesia: Permasalahan Dan Upaya Penanganannya Secara Bilateral Di Kawasan,” Jurnal Ilegal Fishing 1, no. 2012 (3AD): 59-86.

18 . and Setiyono, "Kebijakan Penenggelaman Kapal Asing Pelaku Illegal Fishing Oleh Pemerintah Indonesia Dalam Persfektif Hukum Pidana Internasional."

19 . and Setiyono.
} 
Sumber perikanan di Indonesia masih merupakan sumber kekayaan yang memberikan kemungkinan yang sangat besar untuk dapat dikembangkan bagi kemakmuran bangsa Indonesia, baik untuk memenuhi kebutuhan protein rakyatnya, maupun untuk keperluan ekspor guna mendapatkan dana bagi usaha-usaha pembangunan bangsanya. ${ }^{20}$

\section{Pertahanan dan Keamanan di Wilayah Laut}

Pengaturan mengenai penenggelaman kapal terdapat dalam Pasal 69 yang berbunyi: Pasal 69

(1) Kapal pengawas perikanan berfungsi melaksanakan pengawasan dan penegakan hukum di bidang perikanan dalam wilayah pengelolaan perikanan Negara Republik Indonesia.

(2) Kapal pengawas perikanan sebagaimana dimaksud pada ayat (1), dapat dilengkapi dengan senjata api.

(3) Kapal pengawas perikanan dapat menghentikan, memeriksa, membawa, dan menahan kapal yang diduga atau patut diduga melakukan pelanggaran di wilayah pengelolaan perikanan Negara Republik Indonesia ke pelabuhan terdekat untuk pemrosesan lebih lanjut.

(4) Dalam melaksanakan fungsi sebagaimana ayat (1) penyidik dan atau pengawas perikanan dapat melakukan tindakan khusus berupa pembakaran dan atau penenggelaman kapal perikanan berbendera asing berdasarkan bukti permulaan yang cukup.

Definisi "Kapal pengawas perikanan" adalah kapal pemerintah yang diberi tanda tertentu untuk melakukan pengawasan dan penegakan hukum di bidang perikanan. Penahanan kapal dilakukan dalam rangka tindakan membawa kapal ke pelabuhan terdekat dan/atau menunggu proses selanjutnya yang bersifat sementara. ${ }^{21}$ Yang dimaksud dengan "bukti permulaan yang cukup" adalah bukti permulaan untuk menduga adanya tindak pidana di bidang perikanan oleh kapal perikanan berbendera asing, misalnya kapal perikanan berbendera asing tidak memiliki SIPI dan SIKPI, serta nyata-nyata menangkap dan/atau mengangkut ikan ketika memasuki wilayah pengelolaan perikanan Negara Republik Indonesia. $^{22}$ Ketentuan ini menunjukkan bahwa tindakan khusus tersebut tidak dapat dilakukan dengan sewenang-wenang, tetapi hanya dilakukan apabila penyidik dan/atau pengawas perikanan yakin bahwa kapal perikanan berbendera asing tersebut betulbetul melakukan tindak pidana di bidang perikanan (Penjelasan Pasal 69 ayat (4) Undang-Undang Nomor 45 Tahun 2009 tentang Perikanan).

Penanganan pelaku illegal fishing dengan cara menenggelamkan kapal yang dilakukan oleh Negara Pantai dianggap sah berdasarkan hukum nasional dan hukum internasional yakni UU No. 45 Tahun 2009 tentang Perikanan dan UNCLOS 1982. ${ }^{23}$ Dalam UNCLOS 1982, tidak ada larangan atas kebijakan negara pantai yang melakukan penenggelaman kapal atas

\footnotetext{
${ }^{20}$ Hasjim Djalal, Perjuangan Indonesia Di Bidang Hukum Laut (Bandung: Binacipta, 1979).

${ }^{21}$ tri jata ayu Pramesti, "Dasar Hukum Penenggelaman Kapal Asing Pencuri Ikan," https://www.hukumonline.com/, 2018,

https://www.hukumonline.com/klinik/detail/ulasan/lt54e31f284a8ff/dasar-hukum-penenggelaman-kapal-asingpencuri-ikan/.

${ }^{22}$ wahyu nugroho, "Tindakan Penenggelaman Kapal Perikanan Berbendera Asing Yang Melakukan Illegal Fishing," Studentjournalhukum v, no. 2 (2015): 166-70.

${ }^{23}$ ahmad sofian, "PENINDAKAN DAN PENGHUKUMAN 'ILLEGAL FISHING," 2018, https://businesslaw.binus.ac.id/2018/12/30/penindakan-dan-penghukuman-illegal-fishing/.
} 
pelanggaran zona ekonomi ekslusifnya ${ }^{24}$ Karena UNCLOS 1982 hanya mengatur terkait hukuman bagi pihak yang menjadi terdakwa tidak boleh mencakup pengurungan di negara pantai.

Sanksi penenggelaman kapal yang dilakukan oleh nelayan asing tak hanya dilakukan di Indonesia saja, Australia pun sudah menerapkan sanksi ini sejak lama. Kapal-kapal yang di bakar dan ditenggelamkan tersebut memang tidak terdaftar atau bodong, berdasarkan Hukum Laut Internasional yang diatur dalam Konvensi Perserikatan Bangsa-bangsa tentang kedaulatan penangkapan hanya dapat dilakukan terhadap kapal yang memiliki izin. Antara kedua negara pun harus memiliki perjanjian bilateral tentang Teritorial Laut. ${ }^{25}$

Angkatan Laut memiliki andil yang paling besar dalam menjaga teritorial kelautan Indonesia. Mereka harus memastikan tak ada satu pun kapal asing yang melewati setiap jengakal perbatasan. Sebagai tanggung jawab pelayanan, khususnya dalam hal ini petani. Angkatan Laut harus melakukan transformasi dalam penyelamatan wilayah kelautan dalam negeri. $^{26}$

Terkadang upaya pertahanan perbatasan kenegaraaan dapat membuat ketegangan hubungan antar negara. Namun tak seharusnya Indonesia ragu dan mengalah untuk urusan membela kesejahteraan rakyat, dalam hal ini para nelayan. Pemereintah harus berani mengambil sikap tegas agar tidak direndahkan di mata negara-negara asing. Menilik kembali upaya pertahanan wilayah perairan tahun 1965, bahkan Indonesia sempat memutuskan hubungan dengan China. Keberanian ini diputuskan karena banyak aturan-aturan hukum yang merugikan kedaulatan negara. Terlebih lagi dalam penetapan dua titik Natuna sebaga perbatasan wilayah China yang menjadikan banyak kapal-kapal berbendera asing lalu lalang melintas dengan begitu mudah di laut Indonesia.

Adanya penenggelaman kapal asing terhadap pelaku illegal fishing ini sangat mempengaruhi pertahanan dan keamanan di wilayah laut. Salah satunya adalah semakin sedikitnya kapal negara asing yang melakukan illegal fishing di perairan Indonesia. Karena tidak bisa dipungkiri bahwa penenggelaman kapal memeberikan efek jera bagi pelaku itu sendiri. Sehingga diterapkannya kebijakan penenggelaman kapal ini membuat keamanan dan pertahanan diwilayah laut semakin terjamin.

\section{PENUTUP}

\section{Kesimpulan}

Penenggelaman kapal asing diatur dalam Pasal 69 UU No. 40 Tahun 2009 Tentang Perikanan, Penggelaman kapal tersebut menimbulkan dampak terhadap hubungan Indonesia dengan luar negeri. Tindakan pemerintah Indonesia yang menenggelamkan kapal asing tanpa bernegosiasi dengan negara asalnya dapat mempengaruhi hubungan baik kedua negara. Dampak lain yang timbul dari penenggelaman kapal yakni dampak lingkungan. Dampak negatif yang timbul adalah kandungan logam berat dari kapal yang dapat menyebabkan biota air keracunan.

\footnotetext{
24 ahmad sofian.

${ }^{25}$ Siti Azizah and Shinta Wahyu Purnama Sari, Pengaturan Kawasan (The Area) Dalam Hukum Laut Internasional, Hukum Laut Internasional Dalam Perkembangan, vol. 3, 2014.

${ }^{26}$ Setiono, "Bela Negara Dalam Perspektif Strategi Dan Kebijakan Pertahanan Negara Edisi Khusus 2017."
} 
Penenggelaman itu juga memberi dampak positif yakni pemerintah Indonesia dapat menghentikan aktivitas pencurian ikan serta menyelamatkan habitat perairan di dalam laut dari bahaya bom nelayan asing. Selain itu dapat meningkatkan perekonomian Indonesia dalam bidang ekonomi laut meningkat. Diterapkannya kebijakan penenggelaman kapal ini membuat keamanan dan pertahanan diwilayah laut semakin terjaminBerdasarkan hasil penelitian dan pembahasan mengenai Perlindungan Hukum Terhadap Justice Collaborator dalam Tindak Pidana Narkotika, maka penulis menyimpulkan sebagai berikut:

\section{Saran}

Kementrian kelautan dan perikanan harusnya meminimalisir dampak yang ditimbulkan atas penenggelaman kapal yang dilakukan oleh pihak Indonesia. Karena akibat dari penenggelaman tersebut juga dapat merusak lingkungan laut. Selain itu, ketika didapati pelaku pencurian ikan di wilayah Indonesia dan akan dilakukan penenggelaman kapalnya maka sebaiknya dilakukan negosiasi terlebih dahulu dengan negara kapal, atau setidaktidaknya menghibungi pihak negara kapal agar hubungan diplomatik dengan negara tersebut tetap harmonis.

\section{E. REFERENSI}

Haryanto, and Joko Setiyono. "Kebijakan Penenggelaman Kapal Asing Pelaku Illegal Fishing Oleh Pemerintah Indonesia Dalam Persfektif Hukum Pidana Internasional." Law Reform 13, no. 1 (2017): 70. https://doi.org/10.14710/lr.v13i1.15952.

Admin. "Dampak Pemberantasan Illegal Fishing Dan Penenggelaman Kapal Produksi Ikan Indonesia Meningkat Signifikan." Fakta News, 2017.

ahmad sofian. "Penindakan Dan Penghukuman 'Illegal Fishing," 2018. https://businesslaw.binus.ac.id/2018/12/30/penindakan-dan-penghukuman-illegal-fishing/.

Azizah, Siti, and Shinta Wahyu Purnama Sari. Pengaturan Kawasan (The Area) Dalam Hukum Laut Internasional. Hukum Laut Internasional Dalam Perkembangan. Vol. 3, 2014.

Denny, Septian. “Kapal Yang Ditenggelamkan Menteri Susi Cemari Laut?” Liputan 6, 2016.

Djalal, Hasjim. Perjuangan Indonesia Di Bidang Hukum Laut. Bandung: Binacipta, 1979.

Dkk, Edi Anjarotni. Analisis Dan Evaluasi Hukum Tentang Pengadilan Perikanan. Jakarta: Badan Pembinaan Hukum Nasional, 2009.

Firdaus, Edwin. "Vietnam Protes Penenggelaman Kapal, Tiongkok Minta Penjelasan." Tribun News, 2014.

firmansyah abdul. "Pencurian Ikan Oleh Kapal Asing Di Wilayah Teritorial Indonesia Dalam Presfektif Hukum Positif Indonesia." Lex et Societatis 4, no. 1 (2016): 155-64. https://ejournal.unsrat.ac.id/index.php/lexetsocietatis/article/view/11153/10743.

Kementrian kelautan dan perikanan. Laporan Kinerja Kemenrian Kelautan Dan Perikanan 2017. 1st ed. Vol. 1. jakarta: KKP, 2017. http://kkp.go.id/an-component/media/uploadgambar-pendukung/kkp/LKJ-KKP-2016-Revisi-18-Mei-2017-1.pdf.

Lidkadja, Frans E., and Daniel F. Bassie. Hukum Laut Dan Undang-Undang Perikanan. Jakarta: Ghalia Indonesia, 1985.

Muhamad, Simela Victor. "Illegal Fishing Di Perairan Indonesia: Permasalahan Dan Upaya Penanganannya Secara Bilateral Di Kawasan.” Jurnal Ilegal Fishing 1, no. 2012 (3AD): 59-86.

Septin Puspoayu, Elisabeth, and Peni Jati Setyowati. "Illegal, Unreported, and Unregulated Fishing as Transnational Organized Crimes." SHS Web of Conferences 54 (2018): 05003. https://doi.org/10.1051/shsconf/20185405003. 
ILREJ, Vol. 1, No. 1, Maret 2021

Serina bibina Br. Ginting. "Pengaruh Pemberantasan Illegal Fishing Di Perairan Indonesia Terhadap Hubungan Bilateral Indonesia Dengan Negara Lain.” JOM II, no. II (2015).

Setiono, Kup Yanto. "Bela Negara Dalam Perspektif Strategi Dan Kebijakan Pertahanan Negara Edisi Khusus 2017." Wira Media Informasi Kementerian Pertahanan, 2017, 6.

Sonata, Depri Liber. "Metode Penelitian Hukum Normatif Dan Empiris: Karakteristik Khas Dari Metode Meneliti Hukum.” Jurnal Justicia 8, no. 1 (2008): 24.

tri jata ayu Pramesti. "Dasar Hukum Penenggelaman Kapal Asing Pencuri Ikan." https://www.hukumonline.com/, 2018. https://www.hukumonline.com/klinik/detail/ulasan/lt54e31f284a8ff/dasar-hukumpenenggelaman-kapal-asing-pencuri-ikan/.

Tribawono, Djoko. Hukum Perikanan Indonesia. Jakarta: Citra Aditya Bakti, 2011.

wahyu nugroho. "Tindakan Penenggelaman Kapal Perikanan Berbendera Asing Yang Melakukan Illegal Fishing." Studentjournalhukum v, no. 2 (2015): 166-70.

Yunitasari, Desi. "Penegakan Hukum Di Wilayah Laut Indonesia Terhadap Kapal Asing Yang Melakukan Illegal Fishing Mengacu Pada Konvensi United Nations Convention on Law of the Sea 1982." Jurnal Pendidikan Kewarganegaraan Undiksha 8, no. 1 (2020): 61-78. 